\title{
HYDROCOMPACTION CONSIDERATIONS IN SINKHOLE INVESTIGATIONS
}

\author{
Edward D. Zisman \\ Cardno ATC, 5602 Thompson Center Court, Suite 405, Tampa, Florida 33634 \\ Stephen West \\ BTL Engineering Services, Inc., 5802 North Occident Street, Tampa, Florida 33614
}

\begin{abstract}
The cause of ground settlement is a significant concern in sinkhole investigations where the potential for shallow and deep-seated instability in the subsurface is a major focus of the investigation. Complicating the investigation is the occurrence of hydrocompaction of surficial soils caused by introduction of large amounts of surface water particularly from improper maintenance of rainfall runoff. This condition is usually followed by the subsequent loss of soil moisture during dry periods. This manuscript will discuss how hydrocompaction plays a role in the analysis of settlement in the investigation of sinkhole loss and how one can distinguish between hydrocompaction settlement and deep-seated settlement (note, that hydrocompaction is one of many factors that can account for settlement of structures). It will consider the effects of soil density as it impacts hydrocompaction in the investigation of building distress. Also discussed are the results of laboratory tests of simulated hydrocompaction on fine sand samples in loose and dense states. In one of the tests, the formation of a collapse sinkhole occurred at the end of the test. Photographs depicting the sequence of soil failure are attached at the end of this paper.
\end{abstract}

\section{Introduction}

Most of us have seen the effects of hydrocompaction in the settlement of the soil surface in a flowerpot. In this instance settlement occurs during the extended periods of soil saturation followed by periods of soil drying. These saturated and unsaturated conditions are similar to what occurs to the soil around a building. Other, more extreme examples of how hydrocompaction can be a factor in settlement, is seen in the greater than 30 feet $(9.1 \mathrm{~m})$ of land subsidence that has occurred during a period of over 50 years in the aeolian soils of the San Joaquin valley in California . In this instance, "aquifersystem compaction and hydrocompaction settlements have significantly lowered the land surface since about the 1920s" (Galloway and Riley, 1999). Settlement results from dewatering and the consequential increases in effective soil weight. Hydrocompaction is one component of the settlement we find in the shallow soils near buildings.

\section{Hydrocompaction General}

Hydrocompaction also referred to as hydro-collapse is a process of settlement and resulting volume change that occurs in fine sand with minor amounts of silt and clay. The term hydrocompaction will be used in this paper to describe this process. Hydrocompaction is driven primarily by the infiltration of water into the soil fabric. During wet periods, the continuing infiltration of water into the soil fabric produces a redistribution of soil particles causing the soil to settle while during dry periods settlement occurs (although to a lesser extent in west central Florida) because of an increase in effective stress (Figure 1).

Soils susceptible to hydrocompaction are generally geologically immature soils that have high void ratios and low densities; they can be aeolian deposits or residual soils. These soils are found throughout the United States and have notably caused significant damage in areas where large amounts of water entered the subsurface from leakage in anthropogenic projects. However, the discussions in this paper will be limited to hydrocompaction of loose fill typically found under and around buildings in which sinkhole investigations are being conducted.

\section{Mechanism}

Soils subject to hydrocompaction have one characteristic in common; they have weak structural and chemical bonds between particles. Water infiltrating the soil fabric causes a loss in these bonds. This causes the soil particles to compress in the soil column to more stable positions. As this process continues over time, soil-supporting portions of a structure is lost and a net decrease in soil 
strength occurs in soil supporting the footing. Ultimately, differential settlement may occur as footings must span larger areas of soil to support load. This is a phenomenon seen in many sinkhole investigations.

The repeated saturation and drying of these soils subjects the soil to repeated cycles of tensile and compressive forces that exacerbates settlement. Also the movement of water through the soil causes soil particles to move downward due to erosion (Shlemon, 2004) as the water percolates into the ground surface. Loose fine to medium sands are most susceptible to this condition. As mentioned, a good example of this phenomenon is the settlement that occurs in a flowerpot from the alternate saturated and unsaturated conditions that occur. Over a period of months and sometimes years the surface of the soil undergoes settlement of from 3 to $10 \%$ of the total depth of loose soil (laboratory and field observations). The rate at which this settlement occurs depends on the amount of fines in the soil. The greater the silt and clay content the slower the rate of settlement.

Figures 1A and 1B (after Cassagrande, 1932), provides a graphical representation of the soil microstructure before and after the addition of water. Figure $1 \mathrm{~A}$ is an idealized view of how soil particles appear before the application of water while Figure 1B provides a view of how the soil particles may rearrange after water travels through the soil fabric.

The settlement associated with Figure 1B results not only from weak structural bonds but also from weak chemical bonds between particles. As water moves through the soil fabric, capillary tension between particles is lost and there is a weakening of clay bonds between particles. This causes the soil particles to compress resulting in settlement at the surface.

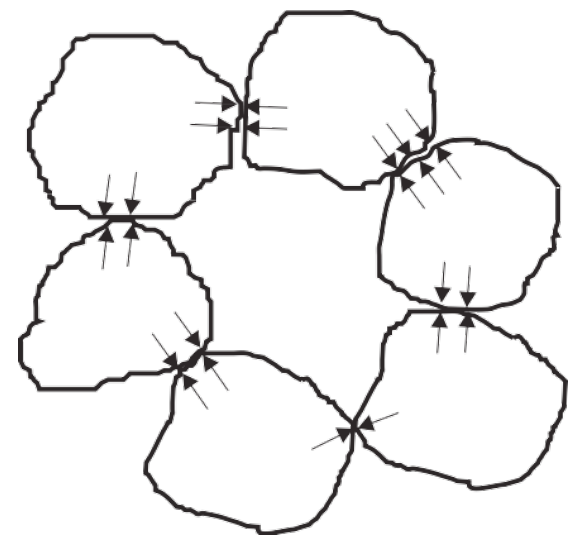

\section{Laboratory Analysis of Settlement}

To aid in understanding the potential and magnitude of hydrocompaction found in various sinkhole investigations, a series of laboratory tests were performed to simulate conditions found at representative sites. The tests consisted of measuring settlement during application of water to sand samples contained in a polycarbonate (lexan)-lined seepage tank. The tank measured 16 inches $(40.6 \mathrm{~cm})$ high by $15 \% 3(40.0$ $\mathrm{cm})$ inches wide by $53 / 8(8.6 \mathrm{~cm})$ inches deep and was constructed as shown in Photo 1.

The seepage tank was filled to a height of approximately $13 \frac{1}{4}$ inches $(33.7 \mathrm{~cm})$ with fine sandy soil typical of that found in west-central Florida. Soil samples were tested in the loose and dense states. The tests were performed with the application of a continuous supply of water entering at the top of the tank to saturate the soil and maintain a constant state of saturation. Flow into the tank was regulated so that inflow was approximately equal to outflow. An observation well was installed to assure there was no ponded water in the tank; the observation well consisted of a $1 / 4$ inch $(0.64 \mathrm{~cm})$ neoprene tube mounted in an aluminum channel section. Settlement of the sand surface was measured with an extensometer recording movement to the nearest thousands of an inch. Measurements were recorded at intervals appropriate to establish the time settlement curves shown in Figures 2 and 3. All tests were continued until settlements had reached an essentially constant rate of elastic change.

This test was designed to approximately simulate the settlement that would occur in loose fill that is typically placed around and possibly under building constructed in south-central Florida. The test was run with no

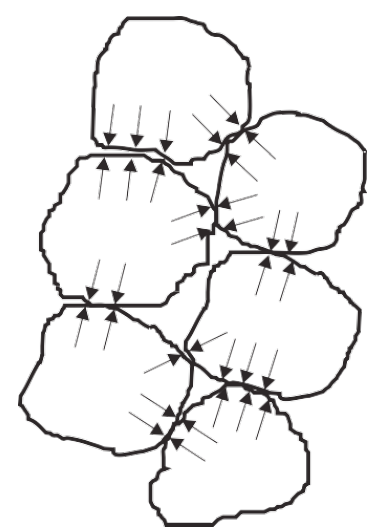

Figure 1. A. Microstructure before application of water. B. Microstructure after application of water. 


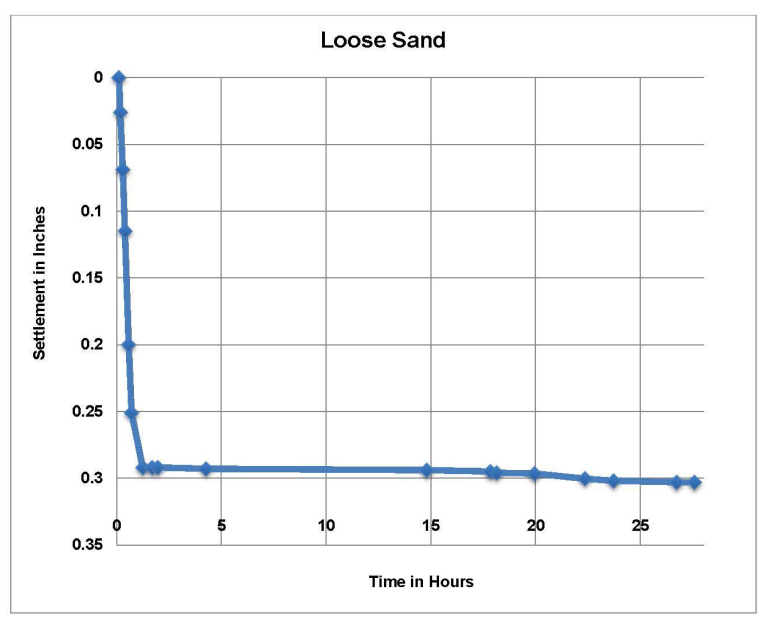

Figure 2. Settlement verses time for loose sand.

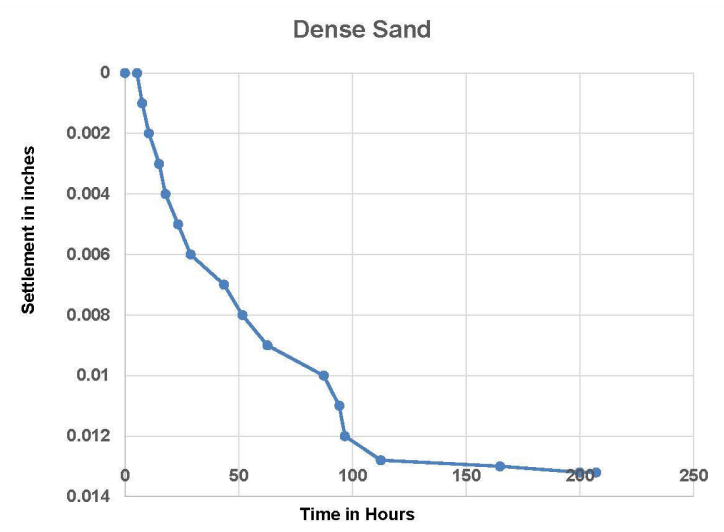

Figure 3. Settlement verses time for dense sand.

surcharge, other than a 3-inch $(7.6 \mathrm{~cm})$ diameter, 440 gm. metal disk resting on the sand that supported the extensometer probe. The sandy soil used in the tests is material commonly used in west-central Florida as fill in areas below and adjoining buildings.

\section{Test Results}

As one would expect, we have found the loose sand had the greater hydrocompaction settlement. Settlement begins with the first application of water and continues at a relatively rapid rate until soil particles move to more stable positions in the soil matrix as shown in Figure 1. After reaching this state, only elastic settlement occurs at a greatly reduced magnitude (see Table 1).

Based on the test results shown in Figures 2 and 3, it is seen that the less dense the soil (high void ratio) the greater the settlement. Table 1 provides a summary of the test results for the two densities corresponding to a loose and dense soil.

\begin{tabular}{|c|c|c|c|c|c|}
\hline$\dot{0}$ & 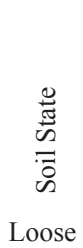 & 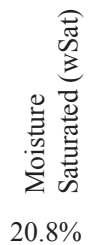 & 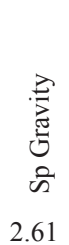 & 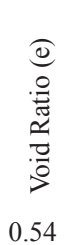 & 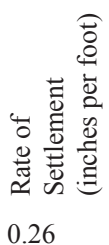 \\
\hline 2 & Dense & $17.5 \%$ & 2.61 & 0.46 & 0.012 \\
\hline
\end{tabular}

Table 1. Test properties and results.

\section{Analysis}

From study of the settlement verses time curves in Figures 2 and 3, it is apparent that two distinct curves define the settlement in each sample. The initial, steeper portion of the curve represents the inelastic component of hydrocompaction settlement. This is the settlement that is characterized by relatively rapid movement of sand as shown in Figure 1A. The second part of the curve represents the elastic component of hydrocompaction shown in Figure 1B.

The distinction between the inelastic and elastic portions of settlement is readily apparent from the abrupt change of slope shown in the time verses settlement curves shown in Figures 2 and 3. This change in slope represents the point when most soil particles have shifted to more stable positions in the soil mass as shown in Figure 1B. The trend is most apparent in loose soil because of the greater ease with which particles can transition to the more stable state characterized by elastic settlement.

A good illustration of settlement associated with hydrocompaction and the subsequent settlement associated with the development of a sinkhole is shown the photographs in Figure 4. In this hydrocompaction experiment, it was found after hydrocompaction settlement was essentially complete, additional settlement occurred associated with the development of a cover collapse sinkhole. The experiment was continued while a small void developed in the sand matrix as soil particles moved to lower positions in the soil section. With the passage of time, at a constant rate of seepage (inflow was approximately equal to discharge through the bottom of the section), the void continued to enlarge until a cover collapse sinkhole developed in the surface of the test section (Photos 1 through 6 in Figure 4).

Ok, so what have we shown? We have shown that hydrocompaction settlement is, for the most part, non- 


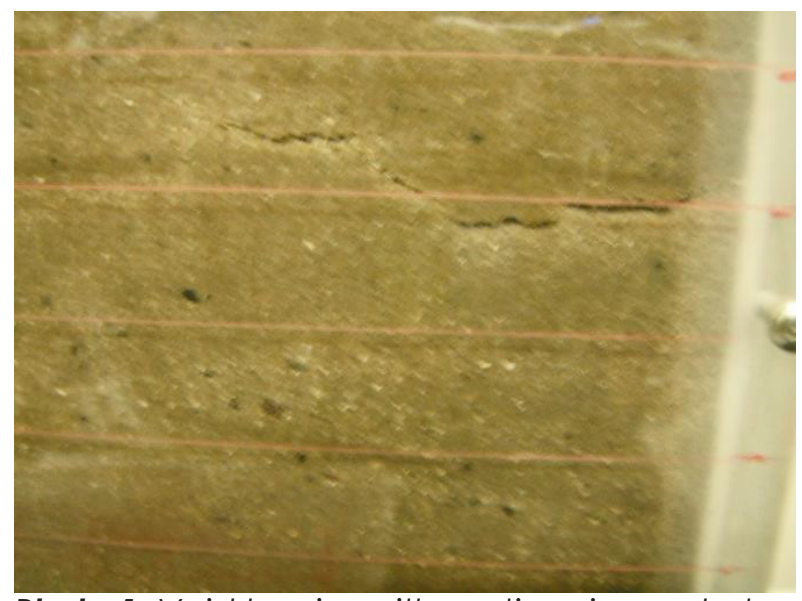

Photo 1. Void begins with partings in sand at course zones.

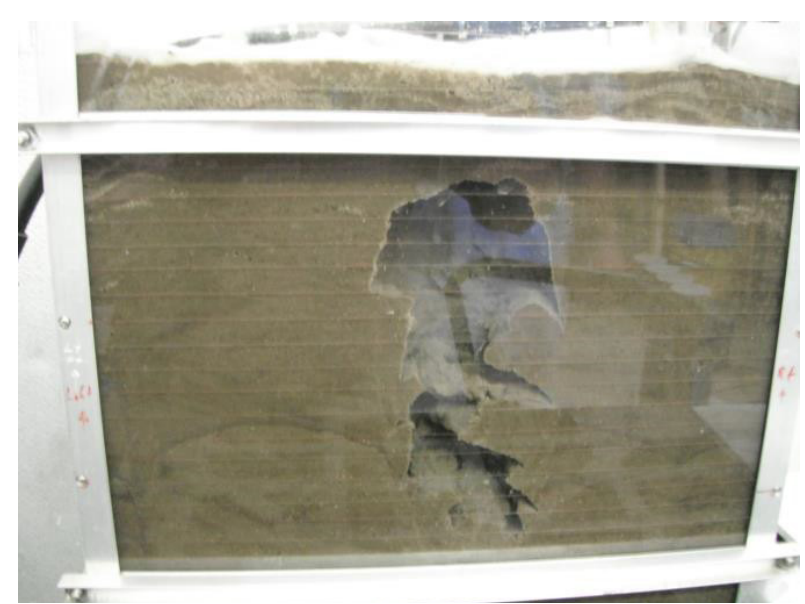

Photo 3. Voids coalescence to form one large void.

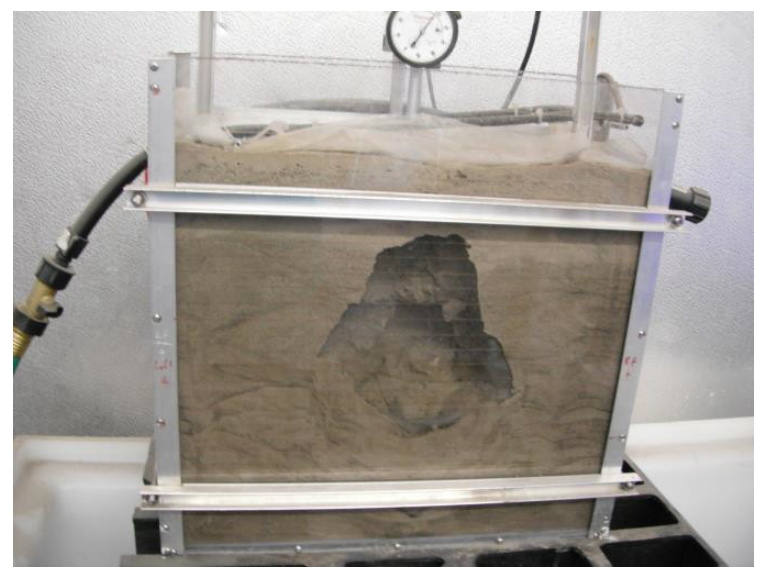

Photo 5. Fully developed void. Note the top geometry has remained constant while sides have expanded to relatively stable position.

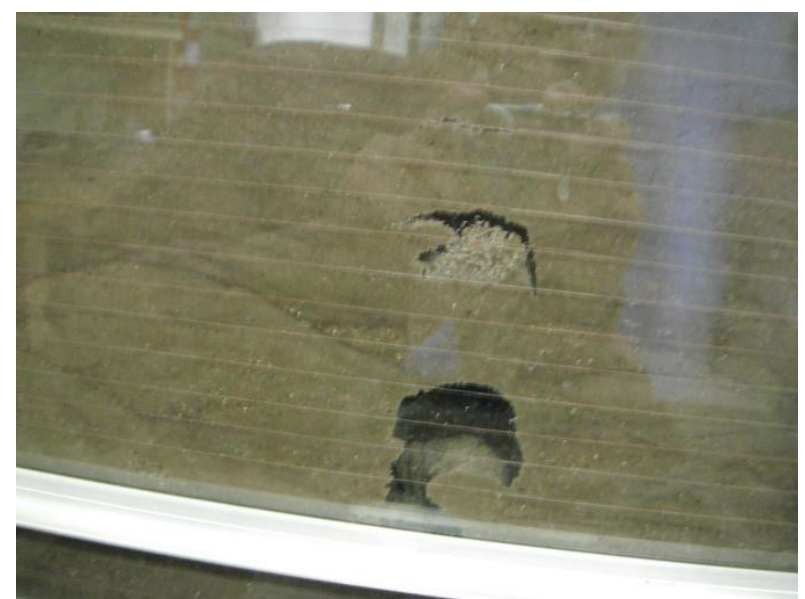

Photo 2. Partings enlarge to form voids.

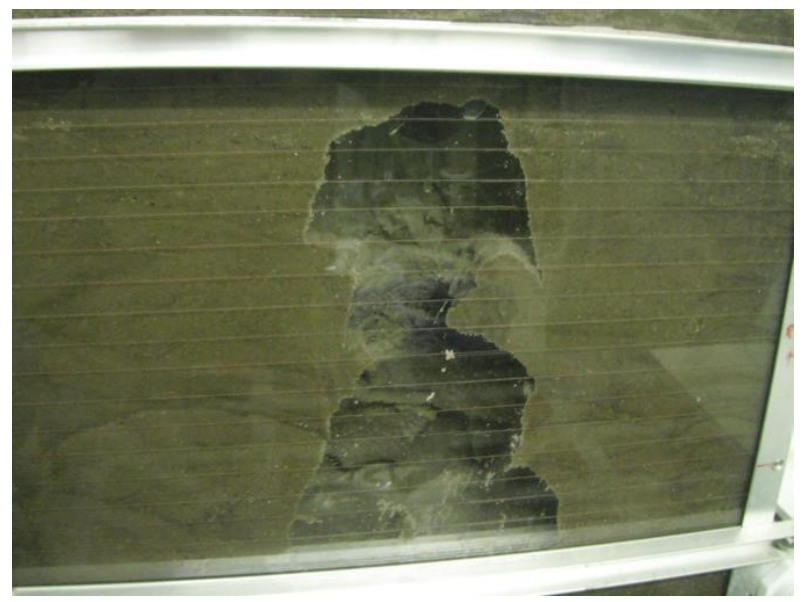

Photo 4. Void enlarging to a more stable configuration.

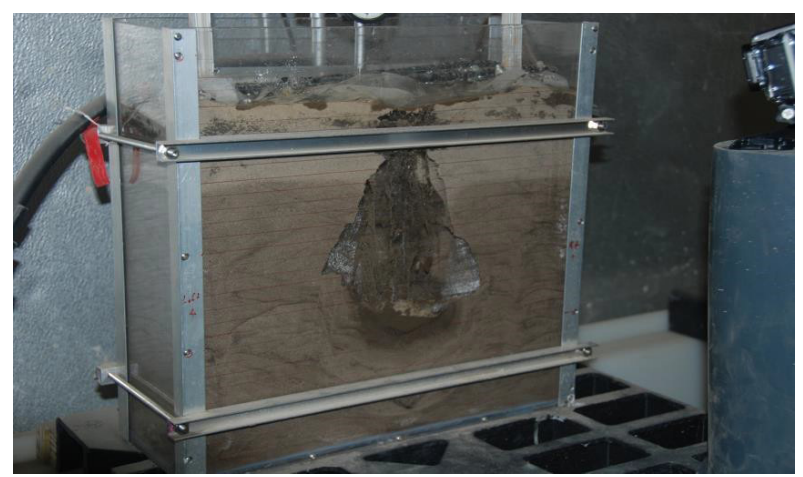

Photo 6. Failure of void roof.

Figure 4. Development of a cover collapse sinkhole. 
elastic it occurs because of movement of soil particles to more stable positions in the soil matrix (Figure 1). This experiment models approximately what happens in nature depending on the frequency, amount of rainfall, soil type etc. From experience, hydrocompaction affects soils to a depth of about 2 to 4 feet $(0.6$ to $1.2 \mathrm{~m})$ below ground surface. Hydrocompaction settlement can be significant in a State where the building code commonly requires foundations to be only 12 inches $(0.3 \mathrm{~m})$ below the ground surface.
The depth affected by hydrocompaction has additional significance in sinkhole investigations as seen from the wording of the Florida sinkhole statute $\$ 627.706$ (Florida Statutes 2014). The statute states that sinkhole activity is present if settlement or weakening of earth supporting the building has occurred (see Figure 5). In some instances, investigators have considered low $\mathrm{N}$-values caused by hydrocompaction as evidence of sinkhole activity (Zisman, 2013). The distinction between hydrocompaction caused by surficial conditions verses raveling caused by deep-seated conditions can, in

\section{Steps in Determining if "Sinkhole Activity" has Occurred According to $\$ 627.706^{1}$}

\section{Steps}

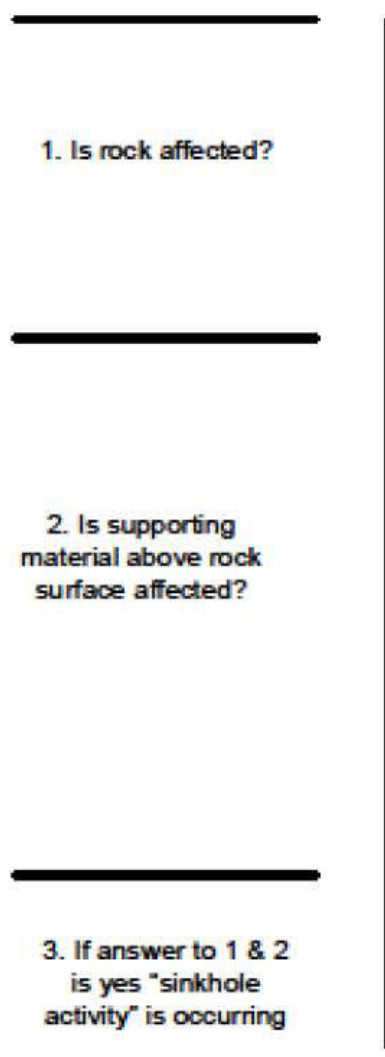

Statute

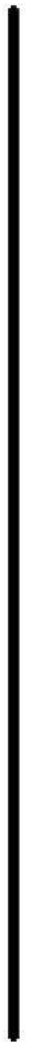

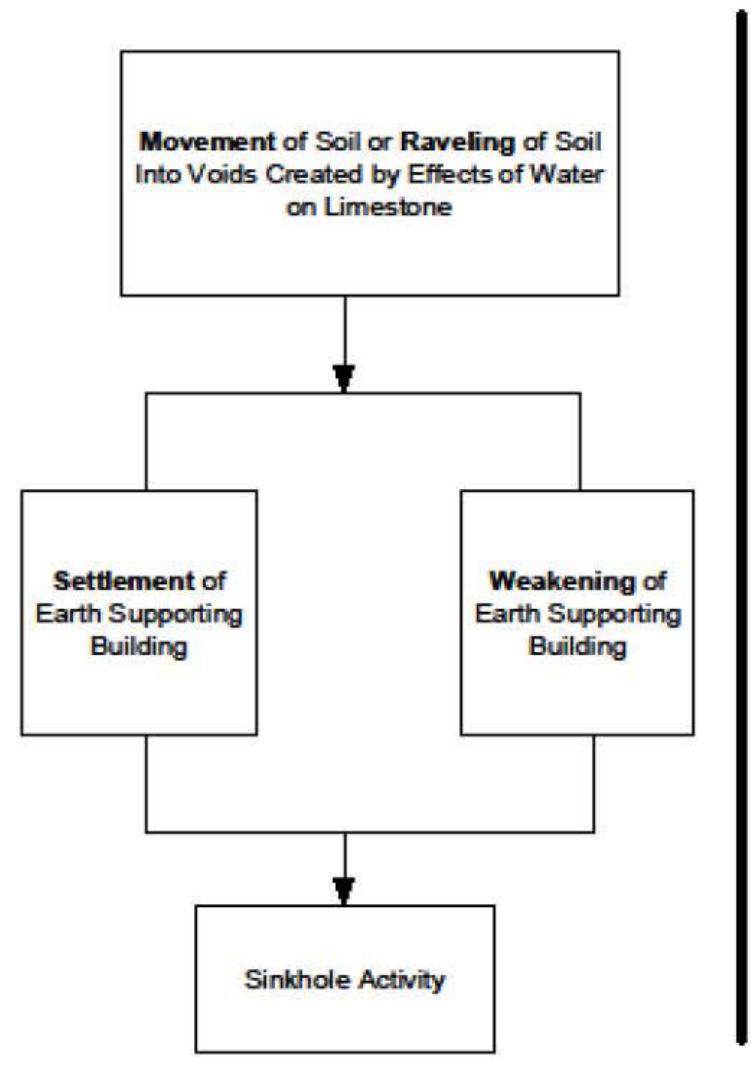

\section{Subsurface}

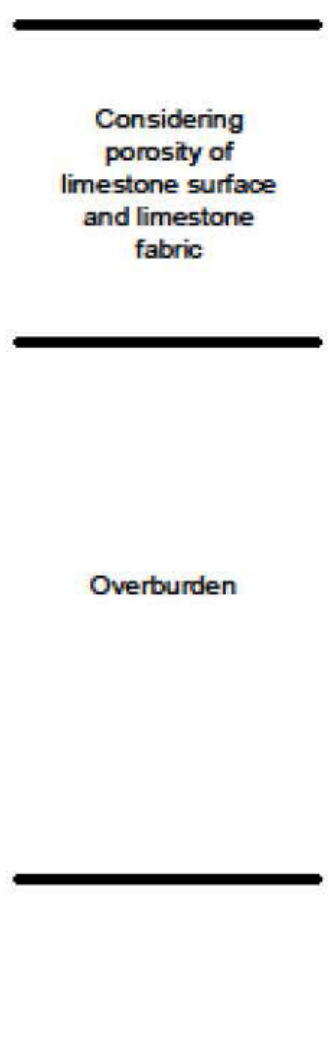

$\$ 627.706$ (d) "Sinkhole activity" means settlement or systematic weakening of the earth supporting such property only when such settlement or systematic weakening results from movement or raveling of soll, sediments, or rock materials into surbterranean voids created by the effect of water on a limestone or similar rock material

${ }^{1}$ This chart is appropriate for most conditions

Figure 5. "Sinkhole activity" according to the Florida statute. 
many cases, be distinguished from the change in N-value that occurs with increasing depth. That is, there must be some evidence that low-density material is present at depth and is related to movement of soil "into subterranean voids created by the effect of water on a limestone or similar rock formation." An obvious distinction would be the change in soil density that occurs at increasing depth below the soils affected by hydrocompaction.

By in large, the greatest damage from hydrocompaction is in buildings constructed without proper compaction of the sandy soils prominent in our area. Deposition of rainwater runoff next to the walls of buildings not equipped with gutters and downspouts to direct water away from the building results in a condition favorable to hydrocompaction settlement.

\section{Settlement Theories}

Although not strictly true, it is acceptable to assume that water and soil grains are incompressible; therefore, the only way settlement can occur in a soil is by movement of the soil grains or collapse of the soil structure. Accordingly, in classical analysis of settlement we generally consider three types of settlement: 1) immediate settlement, 2) consolidation settlement and 3) secondary settlement. However, in hydrocompaction two mechanisms for settlement are present: inelastic and the elastic. The elastic component can be determined by classic methods related to void ratio while the inelastic component can be determined by empirical methods related to void ratio change. Table 2 provides a comparison.

\section{Discussion and Conclusions}

1. From the testing completed, we find that two components of settlement have occurred; one inelastic, the other elastic. The inelastic settlement is characterized by a steep curve while the elastic settlement is characterized by the flatter curve indicative of elastic settlement. Depending on soil density, the magnitude of inelastic settlement is at least an order of magnitude greater than elastic settlement.

2. The location and depth of soils subject to hydrocompaction can be determined by a use of a handheld penetrometer. In general soils having a penetrometer reading of less than $25 \mathrm{~kg} / \mathrm{sq} \mathrm{cm}$ are susceptible to hydrocompaction. The location for penetrometer testing can be expedited by first testing with a probe rod to determine the locations loose/soft soil material.

3. A preliminary estimate of the magnitude of hydrocompaction settlement can be estimated from the value in Table 1 of 0.37 inches / foot $(0.94 \mathrm{~cm} / 30.5 \mathrm{~cm})$ of thickness.

\begin{tabular}{|l|l|l|}
\hline Settlement Mechanisms & Hydrocompaction & Compaction \\
\hline Classic & (Driven essentially by movement of water) & $\begin{array}{l}\text { (Driven by static and dynamic loading under } \\
\text { non-saturated water conditions) } \\
\text { Phase 1. Immediate or elastic }\end{array}$ \\
\hline $\begin{array}{l}\text { (Driven by static and dynamic loading } \\
\text { Phase 1. Immediate or elastic }\end{array}$ & $\begin{array}{l}\text { Phase 1. Immediate or elastic } \\
\text { A. Immediate settlements are inelastic and } \\
\text { can best be approximated from empirical } \\
\text { data related to void ratio }\end{array}$ & $\begin{array}{l}\text { A. Settlement is determined from elastic } \\
\text { theory }\end{array}$ \\
$\begin{array}{l}\text { A. Settlement is determined from elastic } \\
\text { theory }\end{array}$ & $\begin{array}{l}\text { B. Occurs in geologically immature fine } \\
\text { sandy soils with less than about 10\% silt } \\
\text { and clay }\end{array}$ & $\begin{array}{l}\text { B. Occurs in all types of soil because of } \\
\text { elastic compression }\end{array}$ \\
$\begin{array}{l}\text { B. Occurs in all types of soil because of elastion } \\
\text { compression }\end{array}$ & $\begin{array}{l}\text { Phase 2. Consolidation } \\
\text { A. Consolidation is not a factor in } \\
\text { hydrocompaction. }\end{array}$ & $\begin{array}{l}\text { Phase 2. Consolidation } \\
\text { A. Consolidation can be a factor in } \\
\text { settlement. } \\
\text { B. Settlement is determined from the theory } \\
\text { of consolidation }\end{array}$ \\
\hline $\begin{array}{l}\text { Phase 2. Consolidation } \\
\text { water from soil matrix }\end{array}$ & B. Not applicable \\
$\begin{array}{l}\text { B. Settlement is determined from the theory of } \\
\text { consolidation }\end{array}$ & $\begin{array}{l}\text { Phase 3. Secondary } \\
\text { A. Excess pore water pressure is zero } \\
\text { B. Creep settlement occurs from } \\
\text { deformation of soil particles to load. }\end{array}$ & $\begin{array}{l}\text { Phase 3. Secondary } \\
\text { A. Excess pore water pressure is zero } \\
\text { B. Creep settlement occurs from deformation } \\
\text { of soil particles to load. }\end{array}$ \\
$\begin{array}{l}\text { A. Excess pore water pressure is zero } \\
\begin{array}{l}\text { B. Creep settlement occurs from deformation } \\
\text { of soil particles to load. }\end{array}\end{array}$ & \\
\hline
\end{tabular}

Table 2. Settlement theories. 
4. Photographs are shown in Photos 1 through 6 in this paper of a sinkhole that developed in the settling tank when the water was allowed to continue infiltration into the sand soil ultimately resulting in a cover collapse sinkhole.

5. Hydrocompaction occurs in loose sandy soils common in west-central Florida. Buildings constructed without gutters and downspouts to direct water away from the building are vulnerable to hydrocompaction settlement in loose soil.

\section{References}

Cassagrande A. 1932. The Structure of Clay and its importance in foundation engineering; Journal of the Boston Society of Civil Engineers 19 (4): 168-209.

Florida Statutes. 2014. Chapter 627.706 Sinkhole insurance; catastrophic ground cover collapse; definitions.; Division of Law Revision and Information Services, Tallahassee, Florida 32399.

Galloway DL, Riley FS. 1999. San Joaquin Valley California - Largest human alteration of the Earth's surface: Galloway DL, Jones DR, Ingebritsen SE, editors, Land Subsidence in the United States, U.S. Geological Survey Circular 1182.

Shlemon RJ. 2004. Subsidence and ground fissures in southern California: an engineering and geologic perspective: The Shlemon conference Earth Fissures, sponsored by the Association of Engineering Geologist and Engineering Geology.

Zisman ED. 2013. If its weight of hammer conditions, it must be a sinkhole? In: Land L, Doctor DH, Stephenson JB, editors, Proceedings of the 13th Multidisciplinary Conference on Sinkholes \& the Engineering and Environmental Impacts of Karst; 2013 May 6-10; Carlsbad, New Mexico. Carlsbad (NM): National Cave and Karst Research Institute. p. 45-52. 